\section{Determinants of Indonesian Public Listed Companies to Participate in the Tax Amnesty}

\author{
Arie Pratama* \\ ${ }^{1}$ Universitas Padjadjaran, Department of Accounting, Bandung, Indonesia \\ *Correspondence to: Arie Pratama, Universitas Padjadjaran, Department of \\ Accounting, Jalan Dipati Ukur No. 35, Bandung 40132, Indonesia. \\ E-mail: arie.pratama@fe.unpad.ac.id
}

\begin{abstract}
This exploratory research paper would investigate several motivations factors that drive the Indonesian public companies to participate in the Tax Amnesty program. The factors were divided into three: Tax Avoidance, Ownership Structures, and Corporate Governance. We also used profitability, size, and age as a control variable. The data collected from public companies listed in Indonesia Stock Exchange. The data will be taken from 2011-2016 companies' financial statement. There was 135 sample selected using purposive sampling. To analyze the results, we will use binary logistic regressions. The results showed that all the variables mentioned have significant influence toward company's decision to join tax amnesty. The research showed that companies' decision to participate in Tax Amnesty contribute by many factors, however, in each of the factors, there are different views and perspectives.
\end{abstract}

Keywords: tax avoidance, tax amnesty, ownership structure, corporate governance.

Article info: Received 3 May 2018; revised 29 June 2018; accepted 25 July 2018

Recommended citation: Pratama, A. (2018). Determinants of Indonesian Public Listed Companies to Participate in the Tax Amnesty. Indonesian Journal of Sustainability Accounting and Management, 2(2), 136-152.

DOI: 10.28992/ijsam.v2i2.57

\title{
Introduction
}

This paper will investigate several factors that can be a motivation for Indonesian company to follow a Tax Amnesty (TA) programme. Luitel \& Sobel (2007) defined tax amnesty as "Government programs that typically allow a short period of time for tax evaders to voluntarily repay previously evaded taxes without being subject to penalties and prosecution that discovery of such tax evasion normally brings". Buckwalter et al. (2014) stated that amnesty programs typically offer to forgive some or all of the penalties, fees, and interest associated with unpaid tax liabilities. There are several objectives of tax amnesty: 1) Accelerating economic growth and restructuring; 2) promoting tax reform for more equitable taxation system; 3) construct more valid, comprehensive, and integrated tax database extension; and 4) increasing tax revenues (Bose \& Jetter, 2012; The Republic of Indonesia, 2016; Sudarma \& Darmayasa, 2017. Leonard \& Zeckhauser (1987) identify benefits and costs of tax amnesties. The benefits are 1) reduction in the guilt of evaders; 2 ) increase in revenue from voluntary tax payments; 3) addition of former delinquents to the tax rolls; and 4) smoothing the transition to a regime of stricter tax law enforcement. The costs are: 1) increased feelings by honest taxpayers that the tax system is unfair; 2) encouragement of future noncompliance (due to the anticipation of future amnesties) and 
3) reduction in the sense that tax evasion is wrong. Tax Amnesty programme usually designed if there is a big difficulty in government finance, especially concerning the government budget (Mikesell \& Ross, 2012; Buckwalter et al., 2014). Tax revenue in the developing countries can be stable if the government can provide a policy to increase tax revenue (Sharma \& Singh, 2015). Tax revenue in one country might be decreased as a result of international tax competition (Fourcans \& Warin, 2010). In the year 2015, the realization of tax revenue in Indonesia is only $85 \%$. This is the lowest realization rate for the past 8 years. Tax amnesty also designed if there is a problem of low tax compliance. Tax compliance can also be derived by many factors (Pratama, 2017b). During the past 5 years, based on the report provided by Directorate General of Tax, the percentage of the taxpayer that submitting their tax return was only around 50-60\%. To further increase the tax revenue and tax compliance, in the year 2016, Indonesian government issued Law Number 11 in the year 2016 concerning Tax Amnesty. The program's main aims are to improve tax compliance in Indonesia, boost the government's tax revenue and encourage the repatriation of offshore assets (secretly kept in so-called tax havens - using shell companies - where investors can enjoy low tax rates) into Indonesia. Indonesia's tax amnesty program is designed to run for about nine months, starting from 1 July 2016 until 31 March 2017.

Bose \& Jetter (2012) stated that the success of a TA is generally measured in terms of generated revenue and/or a resulting increase in the tax base. The government of Indonesia targets to see the repatriation of IDR 1,000 trillion (approx. USD $\$ 76$ billion) worth of funds that are currently stashed abroad. Tax declarations of on and offshore funds should lead to IDR 165 trillion (approx. USD \$12.5 billion) worth of additional state income. However, in the report issued by Directorate General of Taxes, the effort of tax amnesty still not satisfied enough. The information clearly showed us that although the declaration of funds realization is reaching the target, the state income and repatriation of funds realization is far from satisfactory. One of the cause is the low taxpayer participation. Directorate General of Tax (DGT) showed that until the end of TA programme, there are 810.000 taxpayers that followed the programme. In the year 2016, DGT report showed that there were around 50 million taxpayers, so the ratio of the taxpayer that followed tax amnesty is only $1,62 \%$. If we want to look into Indonesian public companies, from around 438 public listed companies in Indonesia, only 136 that join the TA programme, or only 31,05\%.

The low taxpayer participation can be caused by a voluntary nature of this program. Not all of the taxpayer need to follow the TA programme. It also implied that the decision of taxpayer to follow TA must be caused by one or more motivation and condition. The main motivation of taxpayer to follow tax amnesty is to avoid prosecution and punishment (Bayer et al., 2015). Research conducted by Dubin et al. (1992) showed that if the tax office still conducting tax audit after tax amnesty, the probability of taxpayer to join tax amnesty will decrease rapidly. It can be implied that most of the taxpayers that follow tax amnesty might have a problem with tax compliance (Fisher et al., 1989; Alm et al., 1990; Alm \& Beck, 1993).

Much previous research showed that tax amnesty is a controversial programme. Alm et al. (2009) stated that although several advocates of tax amnesty thought that tax amnesty would increase tax revenue and future compliance, but several countries experience a very small increase in tax revenue, many honest taxpayers resent the government since tax amnesty provide "special treatment" for tax evaders, and tax evaders might reduce their compliance if they think there will be another tax amnesty opportunity in the future. Research conducted by Bayer et al. (2015) stated that tax revenue increase depends on taxpayers decision to take part in amnesties or not. So many previous research stated that tax amnesty didn't contribute to the tax compliance in the long run (Alm et al., 1990; Alm \& Beck, 1993; Torgler \& Schaltegger, 2005). Alm \& Beck (1991) stated that when tax amnesty is not certain, the taxpayer will compare the expected utility gains from following tax amnesty.

This research can contribute theoretically by covering research gaps. First, many research on tax amnesty focused on the effect of tax amnesty to a tax compliance, both in short run and long run (Alm et al., 1990; Alm 
\& Beck, 1993; Alm et al., 2009). There are no or few research publications concerning the cause or motivation of taxpayer to follow the TA. This is perhaps because the previous research was taken a situation where the TA is a mandatory programme. Second, several previous research also took individual taxpayer as a sample (Alm et al., 1990; Alm \& Beck, 1993; Torgler \& Schaltegger, 2005). There is also no research that took corporate taxpayer as a sample. Although individual and corporation can become a taxpayer, there is a different pattern in the tax compliance. The different pattern can lead to a different motivation and condition. Third, this research also provides additional insight by adding tax avoidance, ownership structures, and corporate governance as a motivation factors for a corporate taxpayer. Jones \& Rhoades-Catanach (2016) described tax avoidance as consisting of legitimate means of reducing taxes. Hanlon \& Heitzman (2010) argued that tax avoidance has been defined very broadly. The usual theme of tax avoidance research is noncompliance or aggressiveness. Darussalam \& Septriadi (2010) defined aggressive tax avoidance as an 'unacceptable method of reducing income taxes from point of view of the tax authority, although it is legal to conduct it'. Aggressiveness can take any form, but the main scheme is to utilized intercompany transactions with lacks of arm's length (Doupnik \& Perera, 2015; Pratama, 2017a) and utilizes accounting method to significantly reduce the taxable income (Hanlon \& Heitzman, 2010). Indonesia is a country which has a higher degree of tax avoidance. According to a report provided by Global Financial Integrity in 2015, Indonesian tax avoidance was estimated to be $\$ 297.41$ billion in 2003 and this was approximately three times higher at \$991.3 million in 2012.

The main motivation to establish tax amnesty is to reduce the level of tax avoidance (Malik \& Schwab, 1991; López-Laborda \& Rodrigo, 2005). Andreoni (1991) stated that one of the reasons why taxpayer follows the tax amnesty is to get rid of the past mistakes and can rejoin the tax system, without facing an embarrassment caused by that past mistakes. Marchese \& Privileggi (1997) stated that tax amnesty provides the way for the taxpayer to avoid getting audited or being imposed with a criminal sanction for their past mistakes. Based on the previous research, it can be implied that the taxpayer which has the high level of tax avoidance will have the higher probability to join tax amnesty.

Boyd \& Solarino (2016) argue that corporate ownership is an important factor influencing decision making in business. Ownership structures are defined by the distribution of equity with regard to 1) voting rights, 2) capital invested, and 3) identity and origin of the owners. In the corporation, there is a separation between ownership and control of the company (Annuar et al., 2014). Ownership structure can be varied across the organization and affected the company direction (Badertscher et al., 2013; Holderness, 2016). Ownership can influence the management to do several actions and also different owner has the different style of monitoring and managing, including the decision regarding corporation's tax (Lee \& Kuo, 2014). Shackelford \& Shevlin (2001) stated that ownership structure might have influence over corporate tax avoidance practice, but notice that no or little research literature that explains the relationship between ownership structure and tax avoidance. As the result, several previous research showed that the different group of the owner will have different views about tax avoidance practice, and in this research context, might also have different decision to join tax amnesty program. Indonesia is an emerging country, and as an emerging country, Indonesia company tend to have higher ownership concentration (Mulyadi \& Anwar, 2015). Indonesia company also have a broad variety of owner, some of the famous Indonesia company owned by an individual that belongs to a family, e.g. PT Astra International, Tbk. or PT HM Sampoerna Tbk. Indonesia company might also control by institutional ownership, which can be a domestic or foreign. As the results of this high level of concentration, the owner assumes full control of the company and the owner decision can be usually exercised without heavy objection from the other non controlling owner.

This research will analyze ownership structure based on several views. The first view is an institutional ownership. The institutional ownership view was more long-term rather than the individual investor. Cornett et al. (2007) stated that institutional investors will act as a good corporate monitor. Monitoring the companies, 
especially the public owned, needs lots of effort and cost that only affordable if it conducted by an institutional investor. Navissi \& Naiker (2006) also stated that higher institutional ownership percentage will prevent companies from conducting risky decision, therefore will ensure the stability that will increase the firm value. As the results, the institutional ownership usually was more risk-averse rather than individual ownership (Holderness, 2009; Holderness, 2016). Tax avoidance is a practice that can bring a heavy burden for the company, so the institutional investor will try to avoid that practice. Therefore, it can be expected that the company with high level of monitoring will be less likely to engage in the amnesty, or disclose any irregularities (Buckwalter et al., 2014).

The second view is a managerial ownership. Anthony \& Govindarajan (2007) explained that share-based compensation is one way for a manager to "feel and think" like an owner of a company, so it will be more aligning company and manager's goal. Lee \& Kuo (2014) research found out that higher managerial ownership will reduce agency costs and reduce high-risk activities of the company including tax avoidance practice. However, Joulfaian (2000) research showed that company that managed by the manager that understand about tax will lead to non-compliant act since the manager will utilize loopholes in the tax laws to create tax avoidance. This research implied that manager might also try to lead companies into tax amnesty program to conceal the tax avoidance activities. Francis et al. (2013) stated that publicly owned companies will have more strict requirement for the manager to lead the company, therefore the higher managerial ownership will reduce tax avoidance practice since the manager will be "forced" to comply with the rules and regulation.

The third view is a foreign ownership. Tax avoidance sometimes can be conducted by using multinational companies (MNC) based transactions, like transfer pricing or treaty shopping (Darussalam \& Septriadi, 2010). This MNC usually belongs to a large group controlled by foreign companies. Richardson et al. (2013) showed that foreign ownership is significantly and positively associated with the aggressiveness of tax avoidance practice. Salihu et al. (2015) research also showed that many foreign-owned companies in Malaysia conducting tax avoidance, since the emerging countries usually become the target of $M N C^{\prime}$ 's transfer pricing practices. Therefore, the companies that being part of MNC will tend to utilize tax amnesty program to concealed the international tax avoidance practice. However, a foreign owner that not associated with MNC expected to have different results, Hasan et al. (2016) stated that foreign institutional investor will try to maintain its reputation and tried to show dignity at their host country, and will not conduct any negative acts.

The last view is a family ownership. There is a conflicting result in the previous literature, for example, Chen et al. (2010) explained that family firms tend to be less aggressive, since it tends to protect the reputation, especially in the country in which family entrenchment is deemed not too important. Steijvers \& Niskanen (2014) argue that family firms tend to avoid the practice that can damage the company reputation, including aggressive tax avoidance. However, Sánchez-Marín et al. (2016) indicate that as family firms move to second or third generation, these generations were less tax sophisticated, and tend to be oriented to business.

Corporate governance can reflect how the company valuing good practice in a business. The company that maintains good corporate governance usually engaging in a good practice and avoiding bad practice (Arens et al., 2010). In a context of tax, Lanis \& Richardson (2011) stated that tax always becoming the concern in a business decision. Desai \& Dharmapala (2006) research showed corporate governance affects tax avoidance. Hanlon \& Heitzman (2010) also state that increased monitoring and incentives in governance will reduce 'bad practice' and therefore reduce tax avoidance. First, the quality of the board of commissioners, The monitoring function is conducted by the board of commissioners, which serves as an internal monitoring mechanism to protect the interests of stockholders (Jensen, 1993; Minnick \& Noga, 2010). The board of commissioners performs their function effectively if they can prevent opportunistic management actions (Hermawan, 2011). The board can comprise internal and external commissioners. Several previous studies have shown that larger boards with more internal commissioners tend to have higher agency problems as the 
commissioners have greater power to act only in the interests of majority shareholders (Godfrey, et al., 2010; Scott, 2012). External commissioners provide a more robust monitoring mechanism as they are independent and do not have direct financial interests in the company. Several previous studies have shown that a higher percentage of external directors reduces the level of tax avoidance (Armstrong et al., 2015; Minnick \& Noga, 2010; Taylor \& Richardson, 2013). The board of director effectiveness can't just be measured by looking the size and type of the board, but also need to consider the competence, roles, and activities (Hermawan, 2011). Board competence is strongly needed since strategy of managing company will depend on the level of board knowledge and experience in the business. Tax sometimes perceived as complicated matters that required managers or oversight to learn the tax rules, and they must follow and understand the changing nature of our tax laws and regulations (Saad, 2014). The regulation can be applied consistently if the oversight understands the implication of the tax rules. The activity of the board is also important since, in many corporations in Indonesia, the commissioner can be considered as a ceremonial and only as the symbol (Hidayat \& Utama, 2015; Honggowati et al., 2017). The oversight role of the commissioner will assure the monitoring process run smoothly in the company. This research measured the board effectiveness using effectiveness score index developed by Hermawan (2011). The effectiveness score index measured the effectiveness by looking into 4 different perspectives: types or level of independence, size, activity, and competence.

Second, is the audit committee. The role of the audit committee is to give advice to the board of commissioners concerning financial and audit matters and also to provide a general monitoring mechanism on behalf of the board of commissioners (Abbott \& Parker, 2000). Audit committee members usually have accounting or financial expertise. The audit committee might play a role in tax avoidance. Lanis \& Richardson (2011) stated that independence of the internal audit committee plays an important role in minimizing the possibility of tax aggressiveness within the firm. Rahman \& Ali (2006) showed that audit committee in emerging countries sometimes lack understanding of the relevant organisation rules and make a decision based on the economic perspectives. Therefore, there are also chances that the audit committee will utilize tax amnesty program since it will prevent companies from being audited. Robinson et al. (2012) research also showed that audit committee that understands accounting and tax will suggest the company to conduct tax avoidance since the committee can identify the loopholes in the tax laws. Previous research about audit commitee usually only based on the existence of the committee (Goodwin-Stewart \& Kent, 2006), number of audit committee or expertise level of the committee's member (Beasley et al., 2009), or the activity and the independence (Abbott \& Parker, 2000). The audit committee in Indonesia is mandated by the authority, so to provide correct measurement, analysis must be based on several dimensions (Ika \& Ghazali, 2012) This research also used the effectiveness score index developed by Hermawan (2011) based on 3 different perspectives: competency, activities, and the size.

This research will employ profitability, size, and age as a control variable. There are two theories that can explain action of the company: 1) Stockholder theory and 2) Political cost theory. Stockholder theory indicates the company needs to satisfy the demand of the shareholder, and it is usually a higher asset and higher profit (Gitman \& Zutter, 2015). Political cost theory indicates that the company will try to avoid any action that will cost them a good reputation in the market (Godfrey et al., 2010). Profitability is a common measurement of performance. Higher profitability indicated that company performance is good. But the higher profitability will have resulted in the higher amount of tax, so many high-profit companies will decide to conduct tax avoidance to minimize tax expense (Minnick \& Noga, 2010; Wahab \& Holland, 2012). Dyreng et al. (2008) suggest that firm size play a role in tax management and find that smaller firms have higher tax rates. Rego (2003) argues that larger firms can achieve economies of scale via tax planning and have the incentives and resources readily available to them to reduce the amount of corporate taxes payable. Lanis \& Richardson (2011) argued that larger firms are more likely to be tax aggressive because they possess superior economic and political power 
relative to smaller firms. Scott (2012) argue that the older the company, the broader its business and the higher its reputational risk. The firm will tend to mitigate risk and choose actions that do not trigger higher risk. Since tax avoidance is a risky decision, companies will tend to avoid committing the practice.

Based on the explanation above, the research purpose was to investigate whether tax avoidance, ownership structure, and corporate governance might affect companies' decision to participate in TA. Tax avoidance practice measured using effective tax rate, ownership structures will be measured using institutional, managerial, foreign, and family ownership percentage, Corporate governance will be measured using effectiveness of the board of commissioner and audit committee.

\section{Methods}

Research concerning tax amnesty program in Indonesia is relatively rare, since tax amnesty is usually a one-off program, and the detailed data are usually classified only can be accessed by the tax authority. Therefore, this research can be classified as an exploratory research. Zikmund et al. (2013) defined the exploratory research as a research that conducted for a problem that has not been studied more clearly, intended to establish priorities, develop operational definitions and improve the final research design.

Table 1 Sample Selection Criteria

\begin{tabular}{lc}
\hline \multicolumn{1}{c}{ Information } & Number of Companies \\
\hline Number of companies listed on the IDX in the year 2016 & 514 \\
Number of companies listed on the IDX after 31 December 2011 & $(85)$ \\
Number of companies that do not have a complete financial statement or \\
annual report published on the IDX or company website
\end{tabular}

Researcher select company that listed on the Indonesian Stock Exchange (IDX). There are 514 companies listed in the IDX in the year 2016. Companies that listed in the IDX were required to present the disclosures of the tax amnesty program conducted in 2016, as required by Statement of Financial Accounting Standards (SFAS) No. 70: Accounting for Tax Amnesty's Assets and Liabilities. Other companies that not listed in the IDX cannot be added to the population because they are not required to implement SFAS No. 70, and it's difficult to determine whether they are joined or not, because of the data restrictions.

The researcher select year 2016 to measure the company's participation in tax amnesty. The reason to take the only year 2016 is based on the condition that at the time the researcher conducting this research, the data about company's participation in the year 2017 hadn't been issued yet. Data for independent variables were an unweighted average data from the year 2011-2015 (5 years). The reason for this design is because the tax amnesty program will provide amnesty for the tax year 2011-2015, and tax amnesty participation decision were usually determined by long-term data (Fisher et al., 1989); (Alm \& Beck, 1993). The sample was taken using purposive sampling. Totally, there are 135 companies selected as a sample. The criteria and the number of samples gathered can be seen in Table 1. Variable measurement for this research can be seen in Table 2 . 
Table 2 Variable Measurement

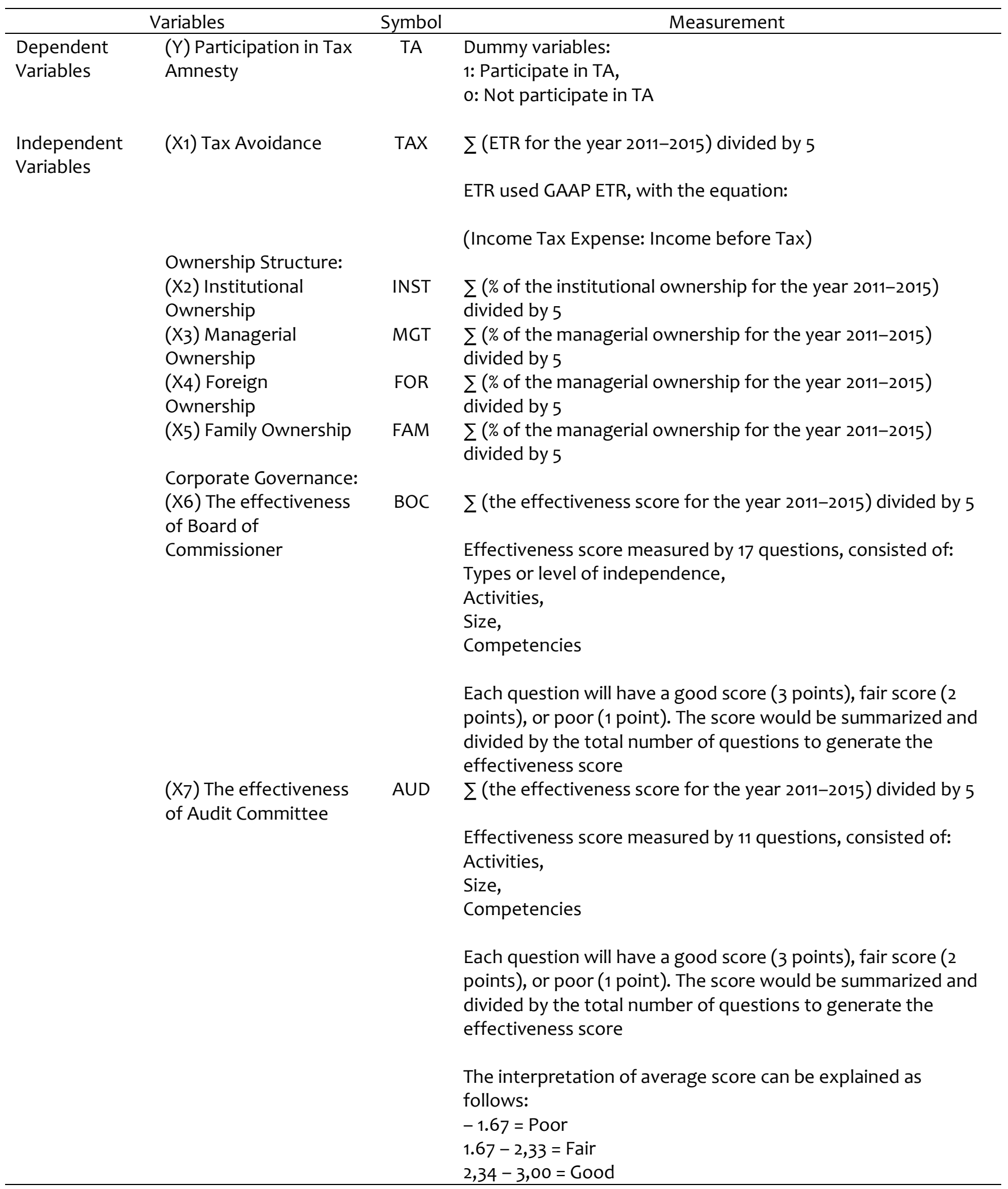


Table 2 (Continued) Variable Measurement

\begin{tabular}{|c|c|c|c|}
\hline & Variables & Symbol & Measurement \\
\hline \multirow{4}{*}{$\begin{array}{l}\text { Control } \\
\text { Variables }\end{array}$} & (X8) Profitability & PROF & $\sum$ (ROA for the year 2011-2015) divided by 5 \\
\hline & & & $\begin{array}{l}\text { ROA measured by using this equation: } \\
\text { Net Income: Total Assets }\end{array}$ \\
\hline & (X9) Size & SIZE & $\sum$ (Ln of Total Assets for the year 2011-2015) divided by 5 \\
\hline & (X10) Age & AGE & The year 2016 - the year of company establishment \\
\hline
\end{tabular}

To test the hypotheses, we used the binary logistic regression analysis model below.

$T A=\alpha_{0}+\alpha_{1} T A X+\alpha_{2} I N S T+\alpha_{3} M G T+\alpha_{4} F O R+\alpha_{5} F A M+\alpha_{6} B O C+\alpha_{7} A U D+\alpha_{8} P R O F+\alpha_{9} S I Z E+\alpha_{10} A G E+\varepsilon$

To test all the hypotheses, we used binary logistic regressions, since the dependent variable (tax) is nominal. There was no need to conduct normality, multicollinearity, or heteroscedasticity tests since logistic regressions rely on the maximum likelihood test.

\section{Results and Discussion}

The variables descriptives can be seen in Table 3. From 135 companies, 27 participate in the tax amnesty in the year 2016. 108 companies didn't participate in 2016's tax amnesty. Some of them tentatively reported in their annual report that they might be followed tax amnesty in the year 2017. Many of them argue that redemption money payment might dry the cash flow and result in the liquidity crisis, therefore the company needs to prepare the cash first. The strict procedure and document to submit related to tax amnesty also became the major factor of why the level of participation for the publicly owned company for the year 2016 is still low. Descriptive statistics showed that the level of tax avoidance in Indonesia's public companies is still high. The average ETR level for the year 2011-2015 is 0.2 or $20 \%$, lower than Indonesia's tax rate of $25 \%$. The statistics even showed us that there is a company that has ETR of $0 \%$. This can be explained because the company has a high amount of deferred tax assets. Accumulation of deferred tax assets will lower the tax expense, resulted in 0 or even negative amount of tax expense. The INST showed that average institutional ownership during 2011-2015 is $40.8 \%$. Institutional ownership has traditionally become the ultimate shareholder of the company. The institutional ownership level can be as high as $96.2 \%$, but however, there are also companies that have no institutional shareholder. Only a few companies in the sample had this kind of situation, mostly they are family companies, in which the shareholders were the family members. MGT showed very low managerial ownership. Compensation in the form of stock is not very popular in Indonesia. Managerial bonus still takes the form of the cash bonus. FOR showed the average foreign ownership is $25.8 \%$ and the maximum percentage is $97.3 \%$. Indonesia currently not have very strict requirements concerning foreign operations and ownership, so it may explain why the variations are so high. FAM percentage is $28.9 \%$, this is quite a large percentage, and it is clearly showed that many public companies in Indonesia were dominated by the family. The descriptive statistics also showed that averagely for the year 2011-2015, the effectiveness of the board of commissioner and audit committee averagely in the "fair" level. The maximum level of both variables was also similar. The maximum effectiveness score for both is 2.8 or in the "good" level. The minimum effectiveness score was also the same, around 1.2 or in the "poor" level. The results showed that the effectiveness of the governance structure in the company still needs to be optimized. The more detailed results based on the effectiveness component showed that most of the companies have the high score in the size and competencies, but scored low in the activities. Therefore, the activities of the board of commissioner and audit committee must be strengthened in the 
future. For the control variables, the average ROA for the year 2011-2015 is 0.07 , the maximum is 0.402 and the minimum is 0.00. the average SIZE for the year 2011-2015 is 29.01 , the maximum is 34.11 and the minimum is 24.59. the average AGE is 36.17 years old, the maximum is 84 years old and the minimum is 6 years.

Table 3 Descriptive Statistics

\begin{tabular}{lccccccccccc}
\hline Measure & TAX & INST & MGT & FOR & FAM & BOC & AUD & PROFIT & SIZE & AGE \\
\hline Mean & 0.200 & 0.408 & 0.075 & 0.258 & 0.289 & 2.083 & 2.121 & 0.076 & 29.01 & 36.17 \\
Maximum & 1.000 & 0.962 & 0.132 & 0.973 & 0.877 & 2.833 & 2.867 & 0.402 & 34.11 & 84 \\
Minimum & 0.000 & 0.000 & 0.000 & 0.000 & 0.000 & 1.283 & 1.200 & 0.001 & 24.59 & 6 \\
Std. Dev. & 0.401 & 0.291 & 0.490 & 0.299 & 0.454 & 0.361 & 0.342 & 0.069 & 2.017 & 14.66 \\
\hline
\end{tabular}

To test the hypotheses, we used a binary logistic regression model. We use logit model since the error distribution of the data is not estimated to follow a normal distribution. To strengthen the model, the researcher also added the robust covariance using Huber-West model. Before checking and interpreting the model, we tested whether it was fit and could be interpreted. Accordingly, we performed the HosmerLemeshow test. Models are considered to be fit if the significance value exceeds $\alpha=5 \%$. As shown in Table 4, the Hosmer-Lemeshow test produced a chi-square value of 3.7916 and a significance value of 0.875 . Since the significance value exceeds $\alpha$, we can conclude that the model is fit and ready to be interpreted. The pseudo-Rsquared of McFadden showed $66.7 \%$ and the percentage correct is $89.6 \%$. High pseudo-R-squared indicate that company's decision to participate in TA may be sufficiently explained by the independent variables, and also the high percentage correct means that the model can predict accurately, so the model can be considered good for interpretation.

We can also see from Table 4, all independent variables were significantly related to the company's decision to participate in TA. This research showed us that the company's decision to participate in TA were driven by several factors. This research showed us the implementation of political cost theory in tax matters. Belz et al. (2018) stated that company's that conduct tax avoidance will face scrutiny for failing to comply with the stakeholder demand - getting profit without risking company's reputation. Tax avoidance considers an act of noncompliance and immoral by the stakeholder, despite the act is deemed legal. Kirchler et al. (2003); Prebble \& Prebble (2010); Dowling (2014) also stated that company that conducts tax avoidance will try to seek assistance to conceal the tax avoidance activities. Therefore, this research showed that tax amnesty participant was the taxpayer that not only evade tax - something that illegal and against the law, but also taxpayer that conduct tax avoidance.

This research also showed us that the ownership structure also affects company's decision to participate in tax amnesty. Ownership act as a principal that will set goals and long-term objectives, and each owner will have their distinctive leadership and goals orientation (Robbins \& Judge, 2013). The first variable of the ownership structure, institutional ownership indeed acts as the best monitoring mechanism to prevent company committing the risky act. Institutional owners were not seeking a short-term profit, but a sustainable profit in the company, and so the institutional owners will be more conservative compared to the noninstitutional owner (Khurana \& Moser, 2013; Khan et al., 2017). The conservative way of managing tax is to do all tax administration and calculation as mandated by the law, and also reduce any volatility of profit (Jones $\&$ Rhoades-Catanach, 2016). 
Table 4 Logistic Regression

\begin{tabular}{|c|c|c|c|c|}
\hline Variable & Coefficient & Std. Error & z-Statistic & Prob. \\
\hline$C$ & 12.282 & 7.703 & 1.594 & 0.1109 \\
\hline TAX & -7.408 & 3.096 & -2.392 & $0.017^{* *}$ \\
\hline INST & -5.407 & 2.521 & -2.144 & $0.032^{* *}$ \\
\hline MGT & -2.901 & 0.866 & -3.346 & $0.001 * * *$ \\
\hline FOR & -6.213 & 2.733 & -2.273 & $0.023 * * *$ \\
\hline FAM & 1.606 & 0.854 & 1.879 & $0.060 *$ \\
\hline $\mathrm{BOC}$ & -3.030 & 1.548 & -1.956 & $0.050^{*}$ \\
\hline AUD & 12.110 & 2.674 & 4.527 & $0.000 * * *$ \\
\hline PROF & -27.581 & 7.913 & -3.485 & $0.000 * * *$ \\
\hline SIZE & -0.435 & 0.228 & -1.901 & $0.058^{*}$ \\
\hline AGE & -0.462 & 0.084 & -5.483 & $0.000 * * *$ \\
\hline McFadden R-squared & & & 0.667 & \\
\hline Percentage Correct & & & $89,6 \%$ & \\
\hline Hosmer Lemeshow & & & 3.7916 & \\
\hline Prob. (HL statistic) & & & 0.875 & \\
\hline LR statistic & & & 90.15 & \\
\hline Prob. (LR statistic) & & & $0.000 * * *$ & \\
\hline
\end{tabular}

*** significant at $\alpha=1 \%$

** significant at $\alpha=5 \%$

* significant at $\alpha=10 \%$

The second variable of the ownership structure, managerial ownership also proved to have the same effect as institutional owners. Managerial owners tend to raise corporate performance since there will be an alignment of company's and manager's interest. Coles et al. (2006); Florackis et al. (2009). Park et al. (2016) stated that managerial owners were usually having higher ability to manage the company and tend to avoid risky practices like tax avoidance. Managerial owners will reduce agency problems and will make manager supporting the owner's interest, so the company won't participate in the tax amnesty.

The third variable, foreign ownership, gives a clear insight into the foreign owners in Indonesia. The statistic result showed that company with high foreign ownership percentage tend to not participate in tax amnesty. Foreign owners in Indonesia seemed to follow the political cost theory. Research by Walsh \& Zhu (2007) stated that the rules enforced in the country will determine the level of foreign company involvement in the business.

The fourth variable, family ownership, also provide more insight into a family business practice in Indonesia. Tax avoidance was present in Indonesian family business practice due to different governance practices resulted from different ownership style (Pratama, 2017c). Chen et al. (2010) explained that family 
owners have substantially higher holdings, they benefit more from tax savings or rent extraction that can be concealed by tax aggressive activities, Sánchez-Marín et al. (2016) indicate that as family firms move to second or third generation, these generations were less tax sophisticated, and tend to be oriented to business, so they conduct more aggressive tax avoidance. Indonesia family business is now owned by second and third generation, so it explained why the level of tax avoidance is high and if tax amnesty can forgive all the tax mistakes, the family owners will reach it.

The results on corporate governance, however, were quite contradictory. The first variable, the effectiveness of the board of commissioners, showed that the company with an effective board of commissioner will not participate in tax amnesty. This results proved that board of commissioner was tended to be more conservative rather than aggressive in monitoring company's performance. Hidayat \& Utama (2015) stated that Indonesia commissioner had several unique characteristics, one of the characteristics is the presence of ex-government officials or even the active government officials. Government officials were usually pushing the companies to conduct every business activities according to the law, and discourage the company to take creative way to provide earnings. Nugroho \& Eko (2011) also stated that Indonesia companies' usually had independent directors that also counterbalance the majority stockholders negative intention, and also advised the companies to act more conservatively. Kusumawati \& Hermawan (2013) also stated that the board activity plays the significant role in board effectiveness. Increasing activity means increasing monitoring and supervisions, and it will prevent companies from conducting negative action or business policy. Minnick \& Noga (2010) stated the board effectiveness will reduce chances for the company to conduct tax avoidance. Less tax avoidance means higher tax compliance, so this kind of company will have lesser chance to participate in tax amnesty.

The second variable, the effectiveness of audit committee showed very different results, it shows that effective audit committee will lead the company to participate in tax amnesty. The audit committee is a part of the board of commissioner, so it expected to have the same trait as the board of commissioner. Kusumawati \& Hermawan (2013) explained that the effectiveness of audit committee will be determined by the knowledge and professionalism of its member. Suprianto et al. (2017) stated that many of Indonesia's company audit committee members have strong knowledge in the field of accounting and taxation, and may advise the company to conduct "creative reporting and management". Sanjaya \& Jati (2015) research also found that audit committee play the significant role in real earnings management, that is providing advice to company management about effective tax planning and management. Waluyo (2017) also proved that audit committee presence will significantly increase tax avoidance practice. The audit committee will recommend the company to participate in tax amnesty, since tax amnesty will provide forgiveness to the company, and will provide a fresh start to re-conduct the practice again (Saraçoğlu \& Çaşkurlu, 2011).

This research also showed that all controls variables influence company's decision to participate in tax amnesty. Profitability showed a negative sign, means that the company with high profitability will not participate in tax amnesty. This results proved that company with high level of profitability already achieve its financial goals. While the company with lower profitability still need to do an effort to achieve high profit, including tax avoidance (Katz et al., 2013). Company with high profitability will tend to do more conservative and avoid committing questionable practice (Isik \& Tasgin, 2017). Questionable practice like tax avoidance might lead to a negative firm value (Zhang et al., 2016). These arguments showed that higher profit company will have less probability to participate in tax amnesty. Size showed the negative sign, means that company with the larger size will not participate in tax amnesty. This results also proved the political cost theory. Company with larger size tend to face more reputation risk (Zadeh \& Eskandari, 2012), since the larger size will attract more eyes from investor and regulator, so this company will keep itself from negative action and policy such as tax avoidance (Wang, 2011). Rego (2003) argues that larger firms can achieve economies of scale and 
have the incentives and resources readily available to them to conduct more proper tax management action, compare to the small firms. Proper tax management action won't attract the attention from the regulator (Jones \& Rhoades-Catanach, 2016), so the need to participate in tax amnesty for larger firms will be low. Age also showed the negative sign, mean that younger age company tend to participate in tax amnesty. Pratama (2017a) stated that the older the company, they tend not to conduct tax avoidance. As the company older, the experience of managing the company and creating a well conservative policy were also increased (Ilaboya \& Ohiokha, 2016; Syahwier \& Fitriani, 2018), so this company is less probable to commit in a questionable act, while the younger companies were usually managed by less experienced management, so the financial performance would still not be optimal (Kholbadalov, 2012). These arguments showed that younger companies will have a higher probability to do more tax avoidance, so they have a higher probability to participate in tax amnesty.

\section{Conclusion}

This research showed that corporate tax payer's participation in TA affected by many factors. Although this research is exploratory, this research showed us several interesting facts. First, this research showed that tax amnesty program utilized by taxpayers for forgiveness for what they're doing in their past activities. The company that participates in tax amnesty had the lower effective tax rate, and by participating in tax amnesty, the past activities won't be subject to tax audit or investigation, therefore will save the company from many negative effects.

Second, This research also proved that different ownership structure had their own goals, and strategies to achieve those goals, including tax matters. This research showed that institutional owners truly played a significant monitoring role to prevent negative action by the company. Managerial owners also reduce the manager's intention to do "creative" management and forced them to act more conservatively and comply with relevant tax laws and regulations. Higher institutional and managerial owners, therefore, will create a taxcomply company and it will less probable that they follow tax amnesty. Research results from foreign owners proved that although they are many MNC in Indonesia, foreign owners still had an orientation to comply to the rules since foreign owners were easy to be exposed if something negative happened. Family owners were proved to be avoiding tax more, so the family owners tend to follow tax amnesty. Overall, this research described the unique characteristics of ownership structure in Indonesia.

Third, this research also proved that effective corporate governance can lead to different decision to participate in Tax Amnesty. While the effective board of commissioner will make the company less probable to follow tax amnesty, the audit committee had vice versa. This result showed the different role of the board in the company. While the board of commissioner is representatives of the owners, the owners tend to be more compliant with tax laws, so the board of commissioner would extend the wishes of owners to the manager. The audit committee, on the other hand, is not directly had the connection with the owner and they tend to act like a professional manager and will act more aggressively compared to the owners.

Fourth, this research also proved that company that already achieve the maturity - high level of probability, higher size, and older in age will be less probable to participate in tax amnesty. The company that already achieved most of the mission will tend to maintain stability and will act less aggressively, compare to the company that still in the stage of introduction and growth.

This research hopefully can give new insight for Directorate General of Tax to understand the demographic map of the corporate taxpayer that became subject to tax amnesty programme. Although tax amnesty is not a routine programme, this research hopefully can supply DGT with information to formulate the new policy for tax amnesty. Last, the Future researcher can expand this research by analyzing tax amnesty 
participation for the year 2016 and 2017, or analyze the effect of tax amnesty participations to microeconomics or macroeconomics indicators of Indonesia.

\section{Acknowledgement}

My highest appreciation for my research assistant teammates: Kelly Kezia Nehemia and Noni Nurazizah that helped me collecting and summarizing the 5-year firm data for me. May the success will always be with all of you. My special appreciation for Dr. Dini Rosdini and Dr. Citra Sukmadilaga for theory and methodology input and suggestions for this paper.

\section{References}

Abbott, L. J., \& Parker, S. (2000). Auditor Selection and Audit Committee Characteristics. Auditing: A Journal of Practice and Theory, 19(2), 47-66. https://doi.org/10.2308/aud.2000.19.2.47

Alm, J., \& Beck, W. (1991). Wiping the Slate Clean: Individual Response to State Tax Amnesties. Southern Economic Journal, 57(4), 1043-1053.

Alm, J., \& Beck, W. (1993). Tax Amnesties and Compliance in the Long Run: A Time Series Analysis. National Tax Journal, 46(1), 53-60.

Alm, J., Martinez-Vazquez, J., \& Wallace, S. (2009). Do Tax Amnesties Work? The Revenue Effects of Tax Amnesties During the Transition in the Russian Federation. Economic Analysis and Policy, 39(2), 235-253. https://doi.org/10.1016/S0313-5926(09)50019-7

Alm, J., McKee, M., \& Beck, W. (1990). Amazing Grace: Tax Amnesties and Compliance. National Tax Journal, 43(1), 23-37.

Andreoni, J. (1991). The Desirability of a Permanent Tax Amnesty. Journal of Public Economics, 45(2), 143-159. https://doi.org/10.1016/0047-2727(91)90037-3

Annuar, H. A., Salihu, I. A., \& Obid, S. N. S. (2014). Corporate Ownership, Governance and Tax Avoidance: An Interactive Effects. Procedia - Social and Behavioral Sciences, 164, 150-160. https://doi.org/10.1016/j.sbspro.2014.11.063

Anthony, R. N., \& Govindarajan, V. (2007). Management Control Systems (12th ed.). Boston: McGraw-Hill/Irwin.

Arens, A. A., Elder, R. J., \& Beasley, M. S. (2010). Auditing and Assurance Services: An Integrated Approach (13th ed.). New Jersey: Pearson.

Armstrong, C. S., Blouin, J. L., Jagolinzer, A. D., \& Larcker, D. F. (2015). Corporate Governance, Incentives, and Tax Avoidance. Journal of Accounting and Economics, 60(1), 1-17. https://doi.org/10.1016/j.jacceco.2015.02.003

Badertscher, B. A., Katz, S. P., \& Rego, S. O. (2013). The Separation of Ownership and Control and Corporate Tax Avoidance. Journal of Accounting and Economics, 56(2-3), 228-250. https://doi.org/10.1016/j.jacceco.2013.08.005

Bayer, R.-C., Oberhofer, H., \& Winner, H. (2015). The Occurrence of Tax Amnesties: Theory and Evidence. Journal of Public Economics, 125, 70-82. https://doi.org/10.1016/j.jpubeco.2015.02.006

Beasley, M. S., Carcello, J. V., Hermanson, D. R., \& Neal, T. L. (2009). The Audit Committee Oversight Process. Contemporary Accounting Research, 26(1), 65-122. https://doi.org/10.1506/car.26.1.3

Belz, T., Hagen, D. von, \& Steffens, C. (2018). Taxes and Firm Size: Political Cost or Political Power? SSRN Electronic Journal.

Bose, P., \& Jetter, M. (2012). Liberalization and Tax Amnesty in a Developing Economy. Economic Modelling, 29(3), 761-765. https://doi.org/10.1016/j.econmod.2012.01.017

Boyd, B. K., \& Solarino, A. M. (2016). Ownership of Corporations: A Review, Synthesis, and Research Agenda. Journal of Management, 42(5), 1282-1314. https://doi.org/10.1177/0149206316633746

Buckwalter, N. D., Sharp, N. Y., Wilde, J. H., \& Wood, D. A. (2014). Are State Tax Amnesty Programs Associated with Financial Reporting Irregularities? Public Finance Review, 42(6), 774-799. https://doi.org/10.1177/1091142113499397 
Chen, S., Chen, X., Cheng, Q., \& Shevlin, T. (2010). Are Family Firms More Tax Aggressive than Non-Family Firms? Journal of Financial Economics, 95(1), 41-61. https://doi.org/10.1016/j.jfineco.2009.02.003

Coles, J. L., Daniel, N. D., \& Naveen, L. (2006). Managerial Incentives and Risk-Taking. Journal of Financial Economics, 79(2), 431-468. https://doi.org/10.1016/j.jfineco.2004.09.004

Cornett, M. M., Marcus, A. J., Saunders, A., \& Tehranian, H. (2007). The Impact of Institutional Ownership on Corporate Operating Performance. Journal of Banking and Finance, 31(6), 1771-1794. https://doi.org/10.1016/j.jbankfin.2006.08.006

Darussalam, J. H., \& Septriadi, D. (2010). Konsep dan Aplikasi Perpajakan Internasional. Jakarta: Danny Darussalam Tax Center.

Desai, M. A., \& Dharmapala, D. (2006). Corporate Tax Avoidance and High-Powered Incentives. Journal of Financial Economics, 79(1), 145-179. https://doi.org/10.1016/j.jfinec0.2005.02.002

Doupnik, T., \& Perera, H. (2015). International Accounting (4th ed.). New York: McGraw-Hill Education.

Dowling, G. R. (2014). The Curious Case of Corporate Tax Avoidance: Is it Socially Irresponsible? Journal of Business Ethics, 124(1), 173-184. https://doi.org/10.1007/s10551-013-1862-4

Dubin, J. A., Graetz, M. J., \& Wilde, L. L. (1992). State Income Tax Amnesties: Causes. The Quarterly Journal of Economics, 107(3), 1057-1070.

Dyreng, S. D., Hanlon, M., \& Maydew, E. L. (2008). Long-Run Corporate Tax Avoidance. The Accounting Review, 83(1), 61-82. https://doi.org/10.2308/accr.2008.83.1.61

Fisher, R. C., Goddeeris, J. H., \& Young, J. C. (1989). Participation in Tax Amnesties: The Individual Income Tax. National Tax Journal, 42(1), 15-27.

Florackis, C., Kostakis, A., \& Ozkan, A. (2009). Managerial Ownership and Performance. Journal of Business Research, 62(12), 1350-1357. https://doi.org/10.1016/j.jbusres.2008.12.001

Fourcans, A., \& Warin, T. (2010). Tax Competition and Information Sharing in Europe: A Signalling Game. International Journal of Economics and Business Research, 2(1/2), 76-86. https://doi.org/10.1504/IJEBR.2010.029730

Francis, B., Sun, X., \& Wu, Q. (2013). Managerial Ability and Tax Aggressiveness. SSRN Electronic Journal.

Gitman, L. J., \& Zutter, C. J. (2015). Principles of Managerial Finance (14th ed.). New York: Pearson.

Godfrey, J., Hodgson, A., Tarca, A., Hamilton, J., \& Holmes, S. (2010). Accounting Theory (7th ed.). New York: John Wiley and Sons, Inc.

Goodwin-Stewart, J., \& Kent, P. (2006). Relation between External Audit Fees, Audit Committee Characteristics and Internal Audit. Accounting and Finance, 46(3), 387-404. https://doi.org/10.1111/j.1467629X.2006.00174.x

Hanlon, M., \& Heitzman, S. (2010). A Review of Tax Research. Journal of Accounting and Economics, 50(2-3), 127-178. https://doi.org/10.1016/j.jacceco.2010.09.002

Hasan, I., Kim, I., Teng, H., \& Wu, Q. (2016). The Effect of Foreign Institutional Ownership on Corporate Tax Avoidance: International Evidence. Bank of Finland Research Discussion Paper.

Hermawan, A. A. (2011). The Influence of Effective Board of Commissioners and Audit Committee on the Informativeness of Earnings: Evidence from Indonesian Listed Firms. Asia Pacific Journal of Accounting and Finance, 2(1), 1-38.

Hidayat, A. A., \& Utama, S. (2015). Board Characteristics and Firm Performance: Evidence from Indonesia. International Research Journal of Business Studies, 8(3), 137-154. https://doi.org/10.21632/irjbs.8.3.137-154

Holderness, C. G. (2009). The Myth of Diffuse Ownership in the United States. Review of Financial Studies, 22(4), 1377-1408. https://doi.org/10.1093/rfs/hhmo69

Holderness, C. G. (2016). Law and Ownership Reexamined. Critical Finance Review, 5, 41-83.

Honggowati, S., Rahmawati, R., Aryani, Y. A., \& Probohudono, A. N. (2017). Corporate Governance and Strategic Management Accounting Disclosure. Indonesian Journal of Sustainability Accounting and Management, 1(1), 23-30. https://doi.org/10.28992/ijsam.v1i1.24

Ika, S. R., \& Ghazali, N. A. M. (2012). Audit Committee Effectiveness and Timeliness of Reporting: Indonesian Evidence. Managerial Auditing Journal, 27(4), 403-424. https://doi.org/10.1108/02686901211217996

Ilaboya, O. J., \& Ohiokha, I. F. (2016). Firm Age, Size and Profitability Dynamics: A Test of Learning by Doing and Structural Inertia Hypotheses. Business and Management Research, 5(1), 29-39. https://doi.org/10.5430/bmr.v5n1p29 
Isik, O., \& Tasgin, U. F. (2017). Profitability and Its Determinants in Turkish Manufacturing Industry: Evidence from a Dynamic Panel Model. International Journal of Economics and Finance, 9(8), 66-75. https://doi.org/10.5539/ijef.v9n8p66

Jensen, M. C. (1993). The Modern Industrial Revolution, Exit, and the Failure of Internal Control Systems. The Journal of Finance, 48(3), 831-880. https://doi.org/10.1111/j.1540-6261.1993.tb04022.x

Jones, S., \& Rhoades-Catanach, S. (2016). Principles of Taxation for Business and Investment Planning. New York: McGraw-Hill Higher Education.

Joulfaian, D. (2000). Corporate Income Tax Evasion and Managerial Preferences. Review of Economics and Statistics, 82(4), 698-701. https://doi.org/10.1162/rest.2000.82.4.698

Katz, S. P., Khan, U., \& Schmidt, A. (2013). Tax Avoidance and Future Profitability. Columbia Business School Research Paper No. 13-10.

Khan, M., Srinivasan, S., \& Tan, L. (2017). Institutional Ownership and Corporate Tax Avoidance: New Evidence. The Accounting Review, 92(2), 101-122. https://doi.org/10.2308/accr-51529

Kholbadalov, U. (2012). The Relationship of Corporate Tax Avoidance, Cost of Debt and Institutional Ownership: Evidence from Malaysia. Atlantic Review of Economics, 2.

Khurana, I. K., \& Moser, W. J. (2013). Institutional Shareholders' Investment Horizons and Tax Avoidance. The Journal of the American Taxation Association, 35(1), 111-134. https://doi.org/10.2308/atax-50315

Kirchler, E., Maciejovsky, B., \& Schneider, F. (2003). Everyday Representations of Tax Avoidance, Tax Evasion, and Tax Flight: Do Legal Differences Matter? Journal of Economic Psychology, 24(4), 535-553. https://doi.org/10.1016/S0167-4870(02)00164-2

Kusumawati, S. M., \& Hermawan, A. A. (2013). The Influence of Board of Commissioners and Audit Committee Effectiveness, Ownership Structure, Bank Monitoring, and Firm Life Cycle on Accounting Fraud. Jurnal Akuntansi Dan Keuangan Indonesia, 10(1), 20-39. https://doi.org/10.21002/jaki.2013.02

Lanis, R., \& Richardson, G. (2011). The Effect of Board of Director Composition on Corporate Tax Aggressiveness. Journal of Accounting and Public Policy, 30(1), 50-70. https://doi.org/10.1016/j.jaccpubpol.2010.09.003

Lee, C.-F., \& Kuo, N.-T. (2014). Effects of Ultimate Ownership Structure and Corporate Tax on Capital Structures: Evidence from Taiwan. International Review of Economics and Finance, 29, 409-425. https://doi.org/10.1016/j.iref.2013.07.004

Leonard, H., \& Zeckhauser, R. (1987). Amnesty, Enforcement and Tax Policy. In L. H. Summers (Ed.), Tax Policy and the Economy (pp. 55-86). Cambridge, MA: MIT Press. https://doi.org/10.3386/w2096

López-Laborda, J., \& Rodrigo, F. (2005). Tax Amnesties and Income Tax Compliance: The Case of Spain. Fiscal Studies, 24(1), 73-96. https://doi.org/10.1111/j.1475-5890.2003.tboo077.x

Luitel, H. S., \& Sobel, R. S. (2007). The Revenue Impact of Repeated Tax Amnesties. Public Budgeting and Finance, 27(3), 19-38. https://doi.org/10.1111/j.1540-5850.2007.00881.x

Malik, A. S., \& Schwab, R. M. (1991). The Economics of Tax Amnesties. Journal of Public Economics, 46(1), $29-49$. https://doi.org/10.1016/0047-2727(91)90063-8

Marchese, C., \& Privileggi, F. (1997). Taxpayers' Attitudes toward Risk and Amnesty Participation: Economic Analysis and Evidence for the Italian Case. Public Finance, 52(3-4), 394-410.

Mikesell, J. L., \& Ross, J. M. (2012). Fast Money? The Contribution of State Tax Amnesties to Public Revenue Systems. National Tax Journal, 65(3), 529-562.

Minnick, K., \& Noga, T. (2010). Do Corporate Governance Characteristics Influence Tax Management? Journal of Corporate Finance, 16(5), 703-718. https://doi.org/10.1016/j.jcorpfin.2010.08.005

Mulyadi, M. S., \& Anwar, Y. (2015). Corporate Governance, Earnings Management and Tax Management. Procedia - Social and Behavioral Sciences, 177, 363-366. https://doi.org/10.1016/j.sbspro.2015.02.361

Navissi, F., \& Naiker, V. (2006). Institutional Ownership and Corporate Value. Managerial Finance, 32(3), 247256. https://doi.org/10.1108/03074350610646753

Nugroho, B. Y., \& Eko, U. (2011). Board Characteristics and Earning Management. Journal of Administrative Science and Organization, 18(1), 1-10.

Park, J., Ko, C. Y., Jung, H., \& Lee, Y.-S. (2016). Managerial Ability and Tax Avoidance: Evidence from Korea. AsiaPacific Journal of Accounting and Economics, 23(4), 449-477. https://doi.org/10.1080/16081625.2015.1017590 
Pratama, A. (2017a). Company Characteristics, Corporate Governance and Aggressive Tax Avoidance Practice: A Study of Indonesian Companies. Review of Integrative Business and Economics Research, 6(4), 70-81.

Pratama, A. (2017b). Machiavellianism, Perception on Tax Administration, Religiosity and Love of Money Towards Tax Compliance: Exploratory Survey on Individual Taxpayers in Bandung City, Indonesia. International Journal of Economics and Business Research, 14(3/4), 356-370. https://doi.org/10.1504/IJEBR.2017.087521

Pratama, A. (2017c). Tax Aggressiveness in Family Firms: Can Corporate Governance Mitigate it? In 1st International Conference on Family Business and Entrepreneurship. Bali.

Prebble, Z. M., \& Prebble, J. (2010). The Morality of Tax Avoidance. Creighton Law Review, 43(3), 693-745.

Rahman, R. A., \& Ali, F. H. M. (2006). Board, Audit Committee, Culture and Earnings Management: Malaysian Evidence. Managerial Auditing Journal, 21(7), 783-804. https://doi.org/10.1108/02686900610680549

Rego, S. O. (2003). Tax-Avoidance Activities of U.S. Multinational Corporations. Contemporary Accounting Research, 20(4), 805-833. https://doi.org/10.1506/VANN-B7UB-GMFA-9E6W

Richardson, G., Taylor, G., \& Lanis, R. (2013). Determinants of Transfer Pricing Aggressiveness: Empirical Evidence from Australian Firms. Journal of Contemporary Accounting and Economics, 9(2), 136-150. https://doi.org/10.1016/j.jcae.2013.06.002

Robbins, S. P., \& Judge, T. A. (2013). Organizational Behavior (15th ed.). Boston: Pearson.

Robinson, J. R., Xue, Y., \& Zhang, M. H. (2012). Tax Planning and Financial Expertise in the Audit Committee. SSRN Electronic Journal.

Saad, N. (2014). Tax Knowledge, Tax Complexity and Tax Compliance: Taxpayers' View. Procedia - Social and Behavioral Sciences, 109, 1069-1075. https://doi.org/10.1016/j.sbspro.2013.12.590

Salihu, I. A., Annuar, H. A., \& Obid, S. N. S. (2015). Foreign Investors' Interests and Corporate Tax Avoidance: Evidence from an Emerging Economy. Journal of Contemporary Accounting and Economics, 11(2), 138-147. https://doi.org/10.1016/j.jcae.2015.03.001

Sánchez-Marín, G., Portillo-Navarro, M.-J., \& Clavel, J. G. (2016). The Influence of Family Involvement on Tax Aggressiveness of Family Firms. Journal of Family Business Management, 6(2), 143-168. https://doi.org/10.1108/JFBM-03-2015-0017

Sanjaya, I. P. S., \& Jati, A. Y. M. (2015). Characteristics of Audit Committee and Real Activities Manipulation: Case from Indonesia. In H. G. Djajadikerta \& Z. Zhang (Eds.), A New Paradigm for International Business. Springer Proceedings in Business and Economics (pp. 227-245). Singapore: Springer. https://doi.org/10.1007/978981-287-499-3_12

Saraçoğlu, O. F., \& Çaşkurlu, E. (2011). Tax Amnesty with Effects and Effecting Aspects: Tax Compliance, Tax Audits and Enforcements Around; The Turkish Case. International Journal of Business and Social Science, 2(7), 95-103.

Scott, W. R. (2012). Financial Accounting Theory (6th ed.). New York: Pearson.

Shackelford, D. A., \& Shevlin, T. (2001). Empirical Tax Research in Accounting. Journal of Accounting and Economics, 31(1-3), 321-387. https://doi.org/10.1016/S0165-4101(01)00022-2

Sharma, P., \& Singh, J. (2015). Determinants of Tax-Revenue in India: A Principal Component Analysis Approach. International Journal of Economics and Business Research, 10(1), 18-29. https://doi.org/10.1504/IJEBR.2015.070268

Steijvers, T., \& Niskanen, M. (2014). Tax Aggressiveness in Private Family Firms: An Agency Perspective. Journal of Family Business Strategy, 5(4), 347-357. https://doi.org/10.1016/j.jfbs.2014.06.001

Sudarma, I. M., \& Darmayasa, I. N. (2017). Does Voluntary Tax Compliance Increase After Granting Tax Amnesty? Accounting and Finance Review, 2(3), 11-17.

Suprianto, E., Suwarno, S., Murtini, H., Rahmawati, R., \& Sawitri, D. (2017). Audit Committee Accounting Expert and Earnings Management with "Status" Audit Committee as Moderating Variable. Indonesian Journal of Sustainability Accounting and Management, 1(2), 49-58. https://doi.org/10.28992/ijsam.v1i2.16

Syahwier, C. A., \& Fitriani, S. A. (2018). Effect of Tax Avoidance, Size of the Company, Leverage, Age of the Company on Cost of Debt in Manufacturing Companies Listed. In Advances in Economics, Business and Management Research. 
Taylor, G., \& Richardson, G. (2013). The Determinants of Thinly Capitalized Tax Avoidance Structures: Evidence from Australian Firms. Journal of International Accounting, Auditing and Taxation, 22(1), 12-25. https://doi.org/10.1016/j.intaccaudtax.2013.02.005

The Republic of Indonesia. Tax Amnesty, Pub. L. No. 11 (2016). Indonesia.

Torgler, B., \& Schaltegger, C. A. (2005). Tax Amnesties and Political Participation. Public Finance Review, 33(3), 403-431. https://doi.org/10.1177/1091142105275438

Wahab, N. S. A., \& Holland, K. (2012). Tax Planning, Corporate Governance and Equity Value. The British Accounting Review, 44(2), 111-124. https://doi.org/10.1016/j.bar.2012.03.005

Walsh, J., \& Zhu, Y. (2007). Local Complexities and Global Uncertainties: A Study of Foreign Ownership and Human Resource Management in China. The International Journal of Human Resource Management, 18(2), 249-267. https://doi.org/10.1080/09585190601102430

Waluyo, W. (2017). Tax Amnesty and Tax Administration System: An Empirical Study in Indonesia. European Research Studies Journal, 20(4B), 548-556.

Wang, X. (2011). Tax Avoidance, Corporate Transparency, and Firm Value. 2011 American Accounting Association Annual Meeting - Tax Concurrent Sessions.

Zadeh, F. O., \& Eskandari, A. (2012). Looking Forward to Financial Risk Disclosure Practices by Malaysian Firms. Australian Journal of Basic and Applied Sciences, 6(8), 208-214.

Zhang, C., Cheong, K. C., \& Rasiah, R. (2016). Corporate Tax Avoidance and Performance: Evidence from China's Listed Companies. Institutions and Economies, 8(3), 61-83.

Zikmund, W. G., Babin, B. J., Carr, J. C., \& Griffin, M. (2013). Business Research Methods (9th ed.). Mason: Cengage. 